\title{
p53 abnormalities in adenocarcinoma of the gastric cardia and antrum
}

\author{
J-F Fléjou, V Gratio, F Muzeau, R Hamelin
}

\begin{abstract}
Aim-To compare the frequency and type of p53 alterations (gene mutation and/or protein overexpression) in a consecutive series of surgically resected adenocarcinomas arising in the gastric cardia and gastric antrum, and to evaluate associations with clinicopathological findings (age, sex, and tumour histology, grade, and stage).

Methods-The series comprised 50 patients with adenocarcinoma of the cardia and 20 patients with adenocarcinoma of the antrum. p53 gene mutations (exons 5-8) were detected by denaturing gradient gel analysis and DNA sequencing. Nuclear p53 overexpression was detected by immunohistochemistry with the DO7 antibody.

Results-p53 gene mutations were found in 21 of 50 and five of 20 adenocarcinomas of the cardia and the antrum, respectively. Base transitions occurring at $\mathrm{CpG}$ dinucleotides were frequent in both types of tumour. p53 protein overexpression was seen in 32 of 50 and seven of 20 adenocarcinomas of the cardia and of the antrum, respectively. p53 gene mutation and/or protein overexpression were significantly more frequent in adenocarcinomas of the cardia ( 37 of 50 ) than in adenocarcinomas of the antrum (seven of 20). There were no differences in the clinicopathological characteristics of the tumours between p53 positive and p53 negative cases in both types of cancer.
\end{abstract}

Conclusions-This study shows that p53 alterations are more frequent in adenocarcinoma of the cardia than in adenocarcinoma of the antrum. This feature is consistent with the clinical and epidemiological characteristics of these cancers, which suggest that adenocarcinoma arising in the gastric cardia might be related to oesophageal adenocarcinoma, and unrelated to adenocarcinomas of the gastric body and antrum.

(f Clin Pathol: Mol Pathol 1999;52:263-268)

Keywords: $\mathrm{p} 53$ gene; $\mathrm{p} 53$ protein; gastric cancer; cardia

NSERM U434, Centre d'Etude du

Polymorphisme

Humain (CEPH),

F-75010, Paris, France

R Hamelin

Correspondence to:

Professor Fléjou.

email: jean-francois.flejou@

bjn.ap-hop-paris.fr

Accepted 8 July 1999 cancer has many features in common with adenocarcinoma of the oesophagus, including a rapidly increasing incidence in most Western countries, a strong male preponderance, and a potential role for tobacco and alcohol consumption. ${ }^{12}$ Oesophageal adenocarcinoma develops most often on Barrett's metaplastic mucosa, a condition that arises in $10 \%$ of patients with chronic gastro-oesophageal reflux disease. This cancer develops through a well characterised histological sequence from metaplasia to dysplasia and eventually cancer. ${ }^{3}$ This group of oesophageal and cardiac adenocarcinomas is distinct from cancers of the gastric body and antrum, which show only a moderate male preponderance, a decreasing incidence, and which have been linked to chronic gastritis and Helicobacter pylori infection. ${ }^{4}$

Among the genetic abnormalities that have been documented in oesophageal and gastric adenocarcinomas, allelic losses on chromosome $17 \mathrm{p}$ and mutations of the p53 gene have been shown to be frequent events. ${ }^{5-7}$ Most studies of oesophageal adenocarcinomas have shown a very high rate of $\mathrm{p} 53$ gene mutation. Moreover, most of the mutations are single base transitions, occurring at $\mathrm{CpG}$ dinucleotides. p53 gene mutations have also been demonstrated in gastric adenocarcinomas, but the influence of the site of the tumour upon the frequency and types of mutation has not been evaluated in most of the published reports. Previously, we have reported significantly higher levels of $\mathrm{p} 53$ protein synthesis and DNA aneuploidy in adenocarcinoma of the cardia when compared with cancer of the antrum. ${ }^{8}$

The aim of our study was to document the frequency and type of p53 abnormalities; that is, gene mutation and/or protein overexpression, in a large series of adenocarcinoma of the gastric cardia, and to compare these features with those observed in a series of adenocarcinomas of the gastric antrum originating from the same centre.

\section{Material and methods}

TISSUE COLLECTION AND HISTOLOGICAL ANALYSIS

Fifty surgically resected specimens were collected from patients with adenocarcinoma of the gastric cardia and 20 specimens from patients with adenocarcinoma of the antrum. Adenocarcinoma of the cardia was defined as a tumour with a centre located within $2 \mathrm{~cm}$ of the oesophago-gastric junction, with no surrounding metaplastic mucosa detected preoperatively or on gross examination of the surgical specimen. ${ }^{9}$ All patients had been treated at Beaujon Hospital from 1991 to 1996. No patient had received chemotherapy or radiotherapy before surgery. Clinicopathological data were collected retrospectively in all patients, by reviewing the clinical charts and all 
histological slides. Patients with cancer of the cardia comprised six women and 44 men aged 29-82 years (median, 64), and those with cancer of the antrum comprised eight women and 12 men aged 38-83 years (median, 63).

Surgical specimens were received fresh, and samples from the tumour were frozen quickly in liquid nitrogen within one hour of surgery and stored at $-80^{\circ} \mathrm{C}$. The specimen was then fixed in formalin for 24 to 48 hours. Samples from the tumour were paraffin wax embedded, serially sectioned, and stained with haematoxylin and eosin. Histological analysis allowed us to classify the tumour according to the WHO, ${ }^{10}$ Lauren, ${ }^{11}$ Ming, ${ }^{12}$ Goseki, ${ }^{13}$ and pTNM $^{14}$ classifications.

\section{IMMUNOHISTOCHEMISTRY}

De-waxed $5 \mu \mathrm{m}$ sections were stained with the primary antibody DO7 (Dakopatts, Glostrup, Denmark) using a three step immunoperoxidase technique enhanced by microwave heating. De-waxed and rehydrated sections were treated by microwave heating in citrate buffer for three times five minutes. Then they were exposed to the primary antibody DO7, at a dilution of $1 / 50$, or to the dilution buffer, for 30 minutes (negative control). The monoclonal antibody DO7 recognises an epitope of human p53 protein located in the $\mathrm{N}$-terminal part of the molecule, between amino acids 19 and $26 .{ }^{15}$ The sections were then incubated sequentially for 30 minutes with a peroxidase labelled rabbit antimouse immunoglobulin antibody and for 30 minutes with a peroxidase labelled swine antirabbit immunoglobulin antibody. These two antibodies were diluted $1 / 200$ in Tris buffered saline (TBS). Visualisation was with diaminobenzidine $(0.6 \mathrm{mg} / \mathrm{ml})$ in the presence of $0.03 \%$ hydrogen peroxide. Haematoxylin was used to counterstain the nuclei lightly. For negative controls the primary antibody was ommitted and for positive controls a Barrett's adenocarcinoma with a positive immunostaining and a well characterised p53 missense mutation was included with each batch. ${ }^{16}$ Results were reported as positive when at least $20 \%$ of cells showed homogeneous and intense nuclear staining. All slides were examined by two independent observers (JFF and FM), and a consensus was obtained by reviewing the slides in divergent cases.

p53 MUTATIONAL ANALYSIS

Genomic DNA was isolated by proteinase $\mathrm{K}$ digestion and phenol/chloroform extraction. Because of a GC rich region in exon 5, a total of five different polymerase chain reaction (PCR) amplifications were performed for screening exons $5-8$ of the p53 gene and their corresponding splice junctions. Sequences of primers and PCR conditions were as described previously. ${ }^{16}$ PCR amplified DNA fragments were analysed by denaturing gradient gel electrophoresis (DGGE). In every instance, negative (without DNA) and positive (with DNA containing a previously identified p53 mutation) controls were amplified by PCR and included in the experiment. Samples were loaded on to $6.5 \%$ polyacrylamide gel (acryla- mide to bisacrylamide, $29: 1$ ) containing the appropriate denaturant gradient parallel to the direction of electrophoresis $(100 \%$ denaturant corresponds to $7 \mathrm{M}$ urea and $40 \%$ deionized formamide). Gradient concentrations and running conditions for each amplified DNA fragment were as described previously. ${ }^{16}$ DNA samples showing PCR products with an altered DGGE profile were amplified and analysed again to confirm their abnormal behaviour and eliminate the possibility of PCR artefacts. These DNA samples were amplified with 5 pmol of a primer with a M13 clamp and 5 pmol of a biotinylated primer. Their sequences were the same as primers for DGGE but without the GC clamp. The PCR conditions were the same as for DGGE. The PCR amplified DNA fragments were purified from the remaining primers by centrifugation through QIAquick columns (Qiagen, Hilden, Germany) and used as templates in a dideoxy termination sequencing procedure using an automated laser fluorescence, ALF express DNA sequencer (Pharmacia Biotech, Uppsala, Sweden).

STATISTICAL ANALYSIS

Statistical analysis of the data was performed using the $\chi^{2}$ test, with a level of significance at $\mathrm{p} \leqslant 0.05$.

\section{Results}

ADENOCARCINOMA OF THE CARDIA

The tumours comprised 34 cases of the intestinal type, 15 of the diffuse type, and one of the mixed type by Lauren's classification. According to Ming's classification, 17 tumours were infiltrative, 27 were expansive, and six had a mixed pattern. According to the Goseki classification, the tumour series included 22 type I tumours, 11 type II tumours, six type III tumours, and 11 type IV tumours. According to the WHO classification, 21 tumours were tubulous, nine were papillary, eight were of the independent cell type, seven were mucinous, two lobular, and three trabecular. According to the UICC staging system, there were two stage IA tumours, three stage IB, nine stage II, and 36 stage IIIA. Table 1 summarises the characteristics of the tumours.

Mutational analysis of exons $5-8$ of the p53 gene resulted in the detection of mutations in 21 adenocarcinomas of the cardia (table 2). A total of 23 mutations was found, because two patients had two distinct mutations. Nine mutations were seen in exon 5, two were seen in exon 6 , one was seen in intron 6 in the splice donor site, five were seen in exon 7 , and six were seeen in exon 8 . These included 18 missense mutations, three nonsense mutations, one frameshift mutation as a result of a one base deletion at codon 173, and one deletion of six base pairs (codons 157 and 158). Thirteen of the single base substitutions were base transitions, with eight occurring at $\mathrm{CpG}$ dinucleotides. The remaining eight single base changes were transversions.

The same 50 tumours were examined by immunohistochemistry. Thirty two adenocarcinomas stained positively with the human p53 
Table 1 Relation between clinicopathological characteristics of tumours and p53 alterations

\begin{tabular}{|c|c|c|c|c|c|c|}
\hline & \multicolumn{3}{|c|}{ Adenocarcinoma of the cardia } & \multicolumn{3}{|c|}{ Adenocarcinoma of the antrum } \\
\hline & $p 53^{+}$ & $p 53^{-}$ & p Value & $p 53^{+}$ & $p 53^{-}$ & $p$ Value \\
\hline \multicolumn{7}{|l|}{ UICC stage } \\
\hline IA & 2 & 0 & \multirow[t]{6}{*}{0.53} & 0 & 0 & \multirow[t]{6}{*}{0.38} \\
\hline IB & 3 & 0 & & 2 & 1 & \\
\hline II & 7 & 2 & & 2 & 3 & \\
\hline IIIA & 25 & 11 & & 3 & 9 & \\
\hline IIIB & 0 & 0 & & 0 & 0 & \\
\hline IV & 0 & 0 & & 0 & 0 & \\
\hline \multicolumn{7}{|l|}{ Lauren's type } \\
\hline Intestinal & 25 & 9 & \multirow[t]{3}{*}{0.20} & 4 & 9 & \multirow[t]{3}{*}{0.59} \\
\hline Diffuse & 12 & 3 & & 3 & 4 & \\
\hline Mixed & 0 & 1 & & 0 & 0 & \\
\hline \multicolumn{7}{|l|}{ Ming's type } \\
\hline Infiltrative & 15 & 2 & \multirow[t]{3}{*}{0.16} & 4 & 7 & \multirow[t]{3}{*}{0.53} \\
\hline Expansive & 17 & 10 & & 3 & 4 & \\
\hline Mixed & 5 & 1 & & 0 & 2 & \\
\hline \multicolumn{7}{|l|}{ Goseki's type } \\
\hline I & 14 & 8 & \multirow[t]{4}{*}{0.53} & 2 & 7 & \multirow[t]{4}{*}{0.54} \\
\hline II & 9 & 2 & & 2 & 2 & \\
\hline III & 5 & 1 & & 0 & 0 & \\
\hline IV & 9 & 2 & & 3 & 4 & \\
\hline \multicolumn{7}{|l|}{ WHO type } \\
\hline Tubulous & 15 & 6 & \multirow[t]{6}{*}{0.57} & 4 & 8 & \multirow[t]{6}{*}{0.64} \\
\hline Papillary & 6 & 3 & & 0 & 1 & \\
\hline Mucinous & 5 & 2 & & 0 & 1 & \\
\hline Trabecular & 2 & 1 & & 0 & 0 & \\
\hline Lobular & 1 & 1 & & 0 & 0 & \\
\hline Independent cells & 8 & 0 & & 3 & 3 & \\
\hline
\end{tabular}

specific monoclonal antibody DO7. In these cases, the staining was exclusively nuclear (fig 1). Stromal cells were unstained. Eighteen cases had no p53 immunoreactivity. Omission of the primary antibody resulted in complete abolition of immunostaining.

There was a significant association between p53 protein immunoreactivity and p53 gene missense mutation ( $p=0.00051)$ (table 3). When we compared the two methods for $\mathrm{p} 53$ mutational analysis, we found that 16 cases showed both p53 gene mutation and protein immunoreactivity. Five cases showed no protein immunoreactivity although they had a gene mutation. Among these five cases, one

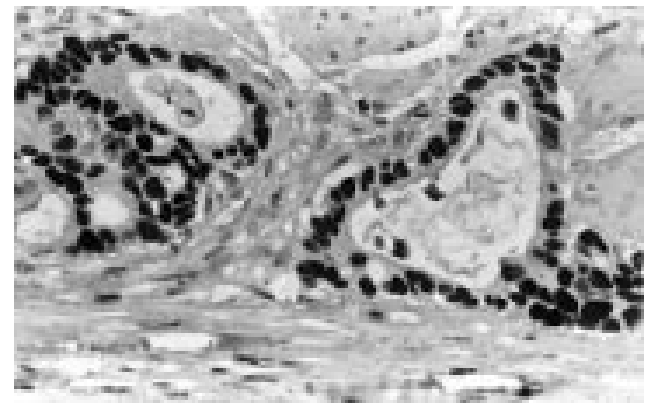

Figure 1 Well differentiated adenocarcinoma of the gastric cardia, showing intense nuclear expression of $p 53$ protein in all tumour cells (DO7 immunostaining).

had a one base deletion and three had a stop mutation. Sixteen cases showed p53 protein immunoreactivity but no gene mutation was detected.

Thirty seven cases showed p53 positive immunostaining and/or gene mutation.

There was no significant difference in the clinicopathological characteristics of the tumours between $\mathrm{p} 53$ positive and negative cases (table 2).

ADENOCARCINOMA OF THE ANTRUM

The tumours comprised 13 cases of the intestinal type and seven of the diffuse type in Lauren's classification. There were 11 infiltrative, seven expansive, and two mixed type tumours according to Ming's classification. According to Goseki's classification, the series included nine type I, four type II, and seven type IV tumours. Following the WHO classification, 12 tumours were tubulous, one was papillary, six were of the independent cell type, and one was mucinous. According to the UICC staging system, there were three type IB tumours, five type II, and 12 type IIIA tumours (table 1).

Table 2 p53 gene mutation in adenocarcinomas of the gastric cardia and of the antrum

\begin{tabular}{|c|c|c|c|c|c|c|c|c|}
\hline Patient no. & $I H C$ & Tumour type & $\begin{array}{l}\text { UICC } \\
\text { stage }\end{array}$ & Exon $^{*}$ & Codon & Nucleotide change & $\begin{array}{l}\text { Nature of nucleotide } \\
\text { substitution }\end{array}$ & Amino acid change ${ }^{\star \star}$ \\
\hline $\mathrm{C} 4$ & + & Cardia & IIIA & 7 & 248 & $\mathrm{CGG} \rightarrow \mathrm{TGG}$ & Ts at $\mathrm{CpG}$ & $\operatorname{Arg} \rightarrow \operatorname{Trp}$ \\
\hline $\mathrm{C} 7$ & + & Cardia & IIIA & 5 & 175 & $\mathrm{CGC} \rightarrow \mathrm{CAC}$ & Ts at $\mathrm{CpG}$ & $\mathrm{Arg} \rightarrow \mathrm{His}$ \\
\hline $\mathrm{C} 8$ & + & Cardia & IIIA & 6 & 213 & $\mathrm{CGA} \rightarrow \mathrm{CTA}$ & $\mathrm{Tv}$ & Arg $\rightarrow$ Leu \\
\hline $\mathrm{C} 14$ & + & Cardia & IB & 5 & 154 & GGC $\rightarrow$ GTC & $\mathrm{Tv}$ & Gly $\rightarrow$ Val \\
\hline C15 & + & Cardia & IIIA & 7 & 259 & GAC $\rightarrow$ GTC & $\mathrm{TV}$ & $\mathrm{Asp} \rightarrow \mathrm{Val}$ \\
\hline C16 & + & Cardia & IIIA & 5 & 175 & $\mathrm{CGC} \rightarrow \mathrm{CAC}$ & Ts at $\mathrm{CpG}$ & Arg $\rightarrow$ His \\
\hline C19 & + & Cardia & IIIA & 8 & 273 & $\mathrm{CGT} \rightarrow \mathrm{TGT}$ & Ts at $\mathrm{CpG}$ & Arg $\rightarrow$ Cys \\
\hline $\mathrm{C} 24$ & - & Cardia & IIIA & 5 & 176 & $\mathrm{TGC} \rightarrow \mathrm{TGA}$ & $\mathrm{Tv}$ & Cys $\rightarrow$ Stop \\
\hline $\mathrm{C} 26$ & - & Cardia & IA & 6 & 196 & $\mathrm{CGA} \rightarrow \mathrm{TGA}$ & Ts at $\mathrm{CpG}$ & Arg $\rightarrow$ Stop \\
\hline $\mathrm{C} 28$ & + & Cardia & IIIA & 7 & 248 & $\mathrm{CGG} \rightarrow \mathrm{CAG}$ & Ts at $\mathrm{CpG}$ & Arg $\rightarrow$ Gln \\
\hline $\mathrm{C} 29$ & - & Cardia & IIIA & 5 & 173 to 174 & GTGAGG $\rightarrow$ GTAGG & & Del 1 bp \\
\hline C31 & + & Cardia & IIIA & 5 & 175 & $\mathrm{CGC} \rightarrow \mathrm{CAC}$ & Ts at $\mathrm{CpG}$ & Arg $\rightarrow$ His \\
\hline C32 & + & Cardia & IIIA & 5 & 133 & $\mathrm{ATG} \rightarrow \mathrm{AGG}$ & $\mathrm{Tv}$ & Met $\rightarrow$ Arg \\
\hline C33 & + & Cardia & IIIA & 8 & 272 & GTG $\rightarrow$ ATG & Ts & $\mathrm{Val} \rightarrow \mathrm{Met}$ \\
\hline C34 & + & Cardia & II & 7,8 & 243,288 & ATG $\rightarrow$ TTG, AAT $\rightarrow$ TAT & $\mathrm{Tv}, \mathrm{Tv}$ & Met $\rightarrow$ Leu, Asn $\rightarrow$ Tyr \\
\hline C36 & + & Cardia & IIIA & 8 & 277 & $\mathrm{TGT} \rightarrow \mathrm{TAT}$ & Ts & Cys $\rightarrow$ Tyr \\
\hline C41 & - & Cardia & II & 7 & 259 & $\mathrm{GAC} \rightarrow \mathrm{GAT}$ & Ts & Asp $\rightarrow$ Asp \\
\hline $\mathrm{C} 46$ & - & Cardia & IIIA & int. 6 & SDS & GTCA $\rightarrow$ ATCA & Ts & Stop \\
\hline $\mathrm{C} 50$ & + & Cardia & IIIA & 8 & 288 & $\mathrm{AAT} \rightarrow \mathrm{AAA}$ & $\mathrm{Tv}$ & Asn $\rightarrow$ Lys \\
\hline C51 & + & Cardia & IA & 8 & 275 & $\mathrm{TGT} \rightarrow \mathrm{TAT}$ & Ts & Cys $\rightarrow$ Tyr \\
\hline C52 & + & Cardia & IIIA & 5,5 & 157 to $158 ; 181$ & del. 6 bp, CGC $\rightarrow-$ CGT & Ts at $\mathrm{CpG}$ & Del 2 aa, Arg $\rightarrow$ Arg \\
\hline $\mathrm{A} 1$ & + & Antrum & II & 6 & 207 & GAT $\rightarrow$ GAA & $\mathrm{Tv}$ & Asp - Glu \\
\hline A5 & + & Antrum & IB & 6,7 & 213,248 & $\mathrm{CGA} \rightarrow \mathrm{CTA}, \mathrm{CGG} \rightarrow \mathrm{TGG}$ & Tv and Ts at CpG & Arg $\rightarrow$ Leu, Arg $\rightarrow$ Trp \\
\hline A7 & + & Antrum & II & 6 & 213 & CGA $\rightarrow$ CAA & Ts at $\mathrm{CpG}$ & Arg $\rightarrow$ Gln \\
\hline A9 & + & Antrum & IB & 8 & 275 & $\mathrm{TGT} \rightarrow \mathrm{TAT}$ & Ts & Cys $\rightarrow$ Tyr \\
\hline A10 & + & Antrum & IIIA & 7 & 245 & $\mathrm{GGC} \rightarrow \mathrm{AGC}$ & Ts & Gly $\rightarrow$ Ser \\
\hline
\end{tabular}

UICC stage IA: TNM = 1, 0, 0; stage IB, TNM =1, 1, 0 and 2, 0, 0; stage II, TNM = 2, 1, 0 and 3, 0, 0; stage IIIA, TNM = 3, 1, 0 and 4, 0,0 .

^Exon exhibiting abnormal denaturing gradient gel electrophoresis (DGGE) profile.

$\star \star$ Predicted change in amino acid sequence as a result of mutation.

aa, amino acid; IHC, immunohistochemistry; int. 6, intron 6; SDS, splice donor site; Del, deletion; bp, base pair; Ts, transition; Tv, transversion. 
Table 3 Comparison between $p 53$ gene missense mutation and $p 53$ protein expression in adenocarcinomas of the gastric cardia and antrum

\begin{tabular}{|c|c|c|c|c|c|c|c|}
\hline & & \multicolumn{6}{|c|}{ p53 gene missense mutation } \\
\hline & & \multicolumn{3}{|l|}{ Cardia } & \multicolumn{3}{|l|}{ Antrum } \\
\hline & & Present & Absent & $p$ Value & Present & Absent & $p$ Value \\
\hline p53 protein expression & $\begin{array}{l}\text { Present } \\
\text { Absent }\end{array}$ & $\begin{array}{r}16 \\
1\end{array}$ & $\begin{array}{l}16 \\
17\end{array}$ & 0.00051 & $\begin{array}{l}5 \\
0\end{array}$ & $\begin{array}{r}2 \\
13\end{array}$ & 0.00043 \\
\hline
\end{tabular}

Mutational analysis of exons $5-8$ of the p53 gene resulted in the detection of mutations in five adenocarcinomas of the antrum (table 2). Because one patient had two distinct mutations, a total of six mutations was found in five patients. Three mutations were seen in exon 6 , two in exon 7, and one in exon 8. These six mutations were missense mutations. Four of the single base substitutions were base transitions, with two occurring at $\mathrm{CpG}$ dinucleotides. The remaining two single base changes were base transversions.

The same 20 tumours were examined by immunohistochemistry. Seven adenocarcinomas stained positively with the human p53 specific monoclonal antibody DO7. Figure 2 shows a well differentiated adenocarcinoma of the gastric antrum that stained negatively for DO7.

There was a significant association between p53 protein immunoreactivity and p53 gene mutation (table 3 ). When we compared the two methods for p 53 mutational analysis, we found that five cases showed both gene mutation and protein immunoreactivity. Two cases showed protein immunoreactivity, but without detectable p53 gene mutation. Overall, we found that seven of 20 tumours of the antrum p53 were positive by immunohistochemistry and/or had p53 gene mutations by molecular analysis.

For adenocarcinoma of the cardia, there was no significant difference in the clinicopathological characteristics of the tumours between p53 positive and p53 negative cases (table 1).

COMPARISON OF p53 ABNORMALITIES BETWEEN ADENOCARCINOMAS OF THE CARDIA AND THE ANTRUM

The frequency of p53 gene mutation and/or p53 protein immunoreactivity was higher in adenocarcinomas of the cardia (37 of 50) when compared with adenocarcinomas of the antrum (seven of 20) $(\mathrm{p}=0.02)$.

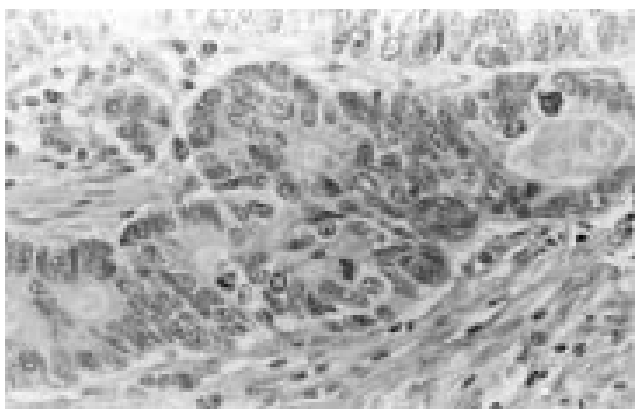

Figure 2 Well differentiated adenocarcinoma of the gastric antrum, $p 53$ negative on immunohistochemistry (DO7 immunostaining).

\section{Discussion}

Our study investigated the frequency of p53 gene mutation and $\mathrm{p} 53$ protein expression in a series of adenocarcinomas arising in the cardia (at the oesophago-gastric junction) and the gastric antrum. The association between p53 abnormalities and pathological characteristics of the tumours was also assessed.

We found a relatively high frequency (21 of 50) of p53 gene mutation in adenocarcinoma of the cardia. This frequency was higher than that observed in adenocarcinoma of the antrum (five of 20). The same difference was observed for $\mathrm{p} 53$ protein overexpression ( 32 of $50 v$ seven of 20), and when any abnormality of p53 (gene mutation and/or protein overproduction) was considered (37 of $50 v$ seven of 20).

A number of studies have reported the frequency of $\mathrm{p} 53$ alterations in gastric cancer, studying either allelic loss on chromosome $17 \mathrm{p}$, p53 gene mutation, or p53 protein overexpression. Between $18 \%$ and $58 \%$ of gastric adenocarcinomas have been found to have p53 mutations, ${ }^{17-20}$ and p53 protein overexpression has been detected in $26-65 \%$ of tumours. ${ }^{21}{ }^{22}$ In most studies, the frequency of p53 alteration was not compared with the location of the tumours in the stomach. The frequency of p53 gene mutation has been shown to be high in two series of adenocarcinomas of the cardia: six of 14 cases by Liang and colleagues ${ }^{23}$ and 26 of 41 cases by Gleeson et al. ${ }^{24}$ However, we found no comparative study between adenocarcinomas arising in the cardia, body, and antrum. This kind of study has been performed for $\mathrm{p} 53$ protein expression detected by immunohistochemistry. In a previous study, we reported a higher frequency of $\mathrm{p} 53$ protein expression in adenocarcinoma of the cardia than in adenocarcinoma of the antrum, ${ }^{8}$ a result that has been confirmed by other studies..$^{2125}$ Therefore, adenocarcinoma of the cardia appears to show a higher frequency of p53 alteration compared with cancer of the lower part of the stomach. A high frequency of p53 alteration has been reported in oesophageal adenocarcinoma (mean percentages of $\mathrm{p} 53$ gene mutation and protein expression $55 \%$ and $61 \%$, respectively) ${ }^{1627}$ and p53 gene mutation is established as a frequent and early event in the carcinogenesis of Barrett's mucosa. ${ }^{28}{ }^{29}$ In the only study comparing p53 alterations in a consecutive series of oesophageal and cardia adenocarcinomas, a high frequency of gene mutation $(70 \% \quad v 63 \%)$ and p53 protein production $(70 \% v 59 \%)$ was observed in both groups of tumours. ${ }^{24}$ Other site specific differences have been reported with respect to the anatomical site of tumours: these differences include a higher frequency of DNA aneuploidy in adenocarcinomas of the cardia and the oesophagus when compared with adenocarcinomas of the antrum, ${ }^{830}$ and a lower frequency of microsatellite instability in oesophageal ${ }^{31} 32$ and cardia $^{33}$ adenocarcinoma. Distal gastric adenocarcinoma shows a range of microsatellite instability similar to that observed in sporadic colon cancer. ${ }^{34}$ In a study reported recently, oesophageal adenocarcinoma and 
adenocarcinoma located at the gastrooesophageal junction showed similar chromosomal gains and losses on comparative genomic hybridisation. ${ }^{35}$ These molecular similarities between cardia and oesophageal adenocarcinomas $^{36}$ are consistent with the hypothesis that these cancers share a common aetiology, distinct from that responsible for the development of adenocarcinomas of the lower part of the stomach. Recent studies demonstrating a parallel increase in the incidence rates of oesophageal and cardia adenocarcinomas ${ }^{2}$ have also suggested that cigarette smoking might contribute to carcinogenesis, along with obesity, which might increase intra-abdominal pressure and predispose to gastro-oesophageal reflux disease. This latter condition is a recognised factor for the development of Barrett's oesophagus, a premalignant condition that predisposes to oesophageal adenocarcinoma. Moreover, it has been proposed that some cases of adenocarcinoma of the cardia might develop from short segment and even "ultrashort segment" Barrett's oesophagus. ${ }^{37}$

It has been suggested that a comparison of the precise type of p53 mutation might indicate whether similar or distinct mechanisms of carcinogenesis are involved in different tumours. ${ }^{38}$ We found a predominance of base transitions and a lower frequency of base transversions in both adenocarcinomas of the cardia and of the antrum. Most transitions occurred at $\mathrm{CpG}$ dinucleotides. This type of mutation is considered to be secondary to an endogenous molecular process resulting from spontaneous deamination of 5'-methylcytosine, leading to $\mathrm{C}$ to $\mathrm{T}$ replacements. A similar pattern of mutation has been reported in other series of adenocarcinoma of the cardia, ${ }^{23}{ }^{24}$ in Barrett's adenocarcinoma, ${ }^{1627}$ and also in most series of gastric adenocarcinoma. ${ }^{17}{ }^{39}$ Although the sites of tumours were not specified in these latter studies, it is very likely that they comprised mainly adenocarcinomas of the antrum. Therefore, it appears that the spectrum of mutation is similar in most adenocarcinomas of the gastrointestinal tract (oesophagus, stomach, and colon), and does not furnish additional data to distinguish between cancers of the gastric cardia and antrum. It must be remembered that the pattern of p 53 mutation is different in squamous cell carcinoma of the oesophagus, with a high frequency of transversions and a low frequency of transitions at $\mathrm{CpG}$ dinucleotides, suggesting that exogenous agents (alcohol and tobacco) are responsible for the mutagenesis. ${ }^{40}$

The presence of $\mathrm{p} 53$ protein overexpression is generally thought to indicate the presence of p53 gene mutation, because most missense mutations lead to the synthesis of a mutant protein with an increased half life. ${ }^{41}$ Our finding of $\mathrm{p} 53$ protein overexpression in most cases with p53 missense mutations is consistent with this opinion. A similar positive correlation between p53 missense mutation and protein expression has been reported in oesophageal and gastric adenocarcinomas. ${ }^{1619} 24$ The presence of five cases of adenocarcinoma of the cardia with p53 gene mutation and no detectable p53 protein show that immunohistochemistry cannot be used as the only method for the detection of p53 alteration. In four of these five cases, the mutation led to the synthesis of an immunonegative truncated protein. We found a relatively high frequency of cases showing p53 protein overexpression with no mutation detected in exons $5-8$ of the p53 gene (16 adenocarcinomas of the cardia and two adenocarcinomas of the antrum). The same types of results, showing partial discrepancies between positive immunohistochemistry and negative mutation screening, have been observed by most authors, and have several explanations. Although the method we used for the detection of p53 gene mutation (DGGE) is considered to be very sensitive, ${ }^{42}$ it is conceivable that some mutations were missed, especially because we studied, by PCR, a mixture of neoplastic and reactive stromal cells, a feature that can obscure the presence of a p53 mutation in some cases. A second possibility is the presence of mutations located outside exons 5-8 of the p5 53 gene, as was reported in $13 \%$ of p53 gene mutations detected in 50 studies that carried out sequencing of the entire coding region of the p53 gene. ${ }^{38}$ The last possibility is that p53 overexpression is the result of a non-mutational stabilisation of this protein, which binds to viral (adenovirus, papilloma virus) or cellular (Mdm2) oncoproteins, a possibility that has not been demonstrated so far in gastric adenocarcinoma. Considering the various explanations for divergent results between p53 gene mutation screening and $\mathrm{p} 53$ protein immunohistochemistry, it appears that both methods are complementary when undertaking detailed analysis of p53 in most tumours.

We found no association between p53 alterations ( $\mathrm{p} 53$ gene mutation and/or protein overexpression) and tumour stage or histological type. Similar results have been reported in most series of adenocarcinomas of the oesophagus and stomach, ${ }^{8162426}$ and have been thought to indicate an early involvement of p53 in the development of these cancers. ${ }^{28}{ }^{29}$ Some studies have shown a higher incidence of p53 alterations in gastric cancers of the intestinal type (Lauren's classification) when compared with the diffuse type, ${ }^{43} 44$ a feature that we were unable to confirm, which might be because of the limited number of cancers of the antrum showing $\mathrm{p} 53$ abnormalities.

In conclusion, our study revealed higher levels of p53 alterations in adenocarcinoma of the cardia compared with adenocarcinoma of the antrum. This result reinforces the hypothesis of a group of cancers of the lower oesophagus and upper stomach with epidemiological, pathogenetic, and molecular characteristics distinct from that observed in cancers of the lower part of the stomach. Adenocarcinomas of the cardia and antrum showed a similar spectrum of p53 gene mutation, with a high frequency of base transition occurring at $\mathrm{CpG}$ dinucleotides. Although there was a relation between p53 gene mutation and p53 protein immunoreactivity, the presence of cases positive only for mutation or for protein overexpression 
underlines the need to perform both techniques when a study of $\mathrm{p} 53$ alteration is undertaken.

The authors thank the Société Nationale Française de Gastro-Entérologie and the Association Charles Debray for their financial support.

1 Morales TG. Adenocarcinoma of the gastric cardia. Dig Dis 1997;15:346-56.

2 Devesa SS, Blot WJ, Fraumeni JF, Jr. Changing patterns in the incidence of esophageal and gastric carcinoma in the United States. Cancer 1998;83:2049-53.

3 Antonioli DA, Wang HH. Morphology of Barrett's esophagus and Barrett's-associated dysplasia and adenocarcinoma. Gastroenterol Clin North Am 1997;26:495-506.

4 Forman D, Webb P, Parsonnet J. Helicobacter pylori and gastric cancer. Lancet 1994;343:243-4.

5 Souza RH, Meltzer SJ. The molecular basis for carcinogenesis in metaplastic columnar-lined esophagus. Gastroenterol Clin North Am 1997;26:583-98.

6 Stemmerman G, Heffelfinger SC, Noffringer A, et al. The molecular biology of esophageal cancer and their precursors: oncogenes, tumor suppressor genes, and growth factors. Hum Pathol 1994;25:968-81.

7 Tahara E, Semba S, Tahara H. Molecular biological observations in gastric cancer. Semin Oncol 1996;23:30715.

8 Fléjou J-F, Muzeau F, Potet F, et al. Overexpression of the p53 tumor suppressor gene product in esophageal and gastric carcinomas. Pathol Res Pract 1994;190:1141-8.

9 Wang $\mathrm{HH}$, Antonioli DA, Goldman H. Comparative features of esophageal and gastric adenocarcinomas: recent
changes in type and frequency. Hum Pathol 1986;17:482-7.

10 Watanabe H, Jass JR, Sobin LH. Histological typing of oesophageal and gastric tumours, World Health Organisation international histological classification of tumours. Berlin: international histological

11 Lauren P. The two histological main types of gastric carcinoma: diffuse and so-called intestinal-type carcinoma. carcinoma: diffuse and so-called intestinal-type

12 Ming SC. Gastric carcinoma. A pathobiological classification. Cancer 1977;39:2475-85.

13 Goseki N, Takizawa T, Koike M. Differences in the mode of the extension of gastric cancer classified by histological type: new histological classification of gastric carcinoma. Gut 1992;33:606-12.

14 Hermanek P, Sobin LH, eds. TNM classification of malignant tumours. Berlin: Springer-Verlag, 1992.

15 Baas IO, Mulder JWR, Offerhaus GJA, et al. An evaluation of six antibodies or immunohistochemistry of mutant p53 gene product in archival colorectal neoplasms. I Pathol 1994;172:5-12.

16 Hamelin R, Flejou J-F, Muzeau F, et al. TP53 gene mutations and $\mathrm{p} 53$ protein immunoreactivity in malignant and premalignant Barrett's esophagus. Gastroenterology and premalignant

17 Renault B, Van Den Broek M, Fodde R, et al. Base transitions are the most frequent genetic changes at p53 in gastric cancer.

18 Seruca R, David L, Castedo S, et al. p53 alterations in gastric carcinoma: a study of 56 primary tumors and 204 nodal metastases. Cancer Genet Cytogenet 1994;75:45-50.

19 Poremba C, Yandell DW, Huang Q, et al. Frequency and spectrum of p 53 mutations in gastric cancer-a molecular genetic and immunohistochemical study. Virchows Arch 1995;426:447-55.

20 Maesawa C, Tamura G, Suzuki Y, et al. The sequential accumulation of genetic alterations characteristic of the colorectal adenoma-carcinoma sequence does not occur between gastric adenoma and adenocarcinoma Pathol 1995;176:249-58.

21 Mönig SP, Eidt S, Zirbes TK, et al. p53 expression in gastric cancer. Clinicopathological correlation and prognostic significance. Dig Dis Sci 1997;42:2463-7.
22 Gomyo $\mathrm{Y}$, Ikeda $\mathrm{M}$, Osaki $\mathrm{M}$, et al. Expression of $\mathrm{p} 21$ (WAF1/CIP1/SDI1), but not p53 protein, is a factor in the (WAF1/CIP1/SDI1), but not p53 protein, is a factor in the survival of patients with

23 Liang YY, Esteve A, Martel-Planche G, et al. p53 mutations n esophageal tumors from high-incidence areas of China. int $\mathcal{F}$ Cancer 1995;61:611-14.

24 Gleeson CM, Soan JM, Mcmanus DT, et al. Comparison of p53 and DNA content abnormalities in adenocarcinoma of the oesophagus and gastric cardia. Br f Cancer 1998;77: 277-86.

25 Shun CT, Wu MS, Lin JT, et al. Relationship of p53 and c-erbB-2 expression to histopathological features, Helicobacter pylori infection and prognosis in gastric cancer. Hepatogastroenterology 1997;44:604-9.

26 Starzynska T, Bromley M, Ghosh A, et al. Prognostic significance of p 53 overexpression in gastric and colorectal carcinoma. Br 7 Cancer 1992;66:558-62.

27 Gleeson CM, Sloan JM, Mcguigan JA, et al. Base transitions at $\mathrm{CpG}$ dinucleotides in the p53 gene are common in

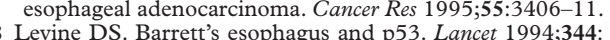
Levine DS.
$212-13$.

29 Neshat K, Sanchez CA, Galipeau PC, et al. p53 mutations in Barrett's adenocarcinoma and high-grade dysplasia. Gastroenterology 1994;106:1589-95.

30 Johnson H, Belluco C, Masood S, et al. The value of flow cytometric analysis in

31 Muzeau F, Flejou J-F, Belghiti J, et al. Infrequent microsatellite instability in oesophageal cancers. $\mathrm{Br} \mathcal{F}$ Cancer ellite instability

32 Gleeson CM, Sloan JM, Mcguigan JA, et al. Ubiquitous somatic alterations at microsatellite alleles occur infrequently in Barrett's-associated oesophageal adenocarcinoma. Cancer Res 1996;56:259-63.

33 Gleeson CM, Sloan JM, Mcguigan JA, et al. Widespread microsatellite instability occurs infrequently in adenocarcinoma of the gastric cardia. Oncogene 1996;12:1653-62.

34 Dos Santos NR, Seruca R, Constancia M, et al. Microsatellite instability at multiple loci in gastric carcinoma: clinicopathologic implications and prognosis. Gastroenterology 1996;110:38-44.

35 Van Dekken H, Geelen E, Dinjens WNM, et al. Comparative genomic hybridization of cancer of the gastroesophageal junction: deletion of 14031-32.1 discriminates between esophageal (Barrett's) and gastric cardia adenocarcinomas. Cancer Res 1999;59:748-52.

36 Wu TT, Watanabe T, Heitmiller R, et al. Genetic alterations in Barrett esophagus and adenocarcinomas of the esophagus and esophagogastric junction region. Am $\mathcal{F}$ Pathol 1998;153:287-94

37 Cameron AJ, Lomboy CT, Pera M, et al. Adenocarcinoma of the esophagogastric junction and Barrett's esophagus. Gastroenterology 1995;109:1541-6.

38 Greenblatt MS, Bennett WP, Hollstein M, et al. Mutations in the p53 tumor suppressor gene: clues to cancer etiology and molecular pathogenesis. Cancer Res 1994;54:4855-78.

39 Uchino S, Noguchi M, Ochiai A, et al. p53 mutation in gastric cancer: a genetic model for carcinogenesis is common to gastric and colorectal cancer. Int $\mathcal{F}$ Cancer 1993;54:75964 .

40 Montesano R, Hollstein M, Hainaut P. Genetic alterations in esophageal cancer and their relevance to pathogenesis: a review. Int 7 Cancer 1996;69:225-35.

41 Soussi T, Legros Y, Lubin R, et al. Multifactorial analysis of p53 alteration in human cancer: a review. Int 7 Cancer 1994;57:1-9.

42 Hamelin R, Jego N, Laurent-Puig P, et al. Efficient screening of p53 mutations by denaturing gradient gel electrophoresis in colorectal tumors. Oncogene 1993;8:2213-20.

43 Gabbert HE, Muller W, Schneiders A, et al. The relationship of $\mathrm{p} 53$ expression to the prognosis of 418 patients with gastric carcinoma. Cancer 1995;76:720-6.

44 Hurlimann J, Saraga EP. Expression of p53 protein in gastric carcinomas. Association with histologic type and prognosis. Am $\mathcal{F}$ Surg Pathol 1994;18:1247-53. 